УДК 341.213.5

DOI https://doi.org/10.17308/vsu.proc.law.2021.3/3540

\section{О НЕТИПИЧНЫХ ФОРМАХ ПРАВЛЕНИЯ: СПЕЦИФИКА И СУЩНОСТЬ ГОСУДАРСТВЕННО-ПРАВОВОГО УСТРОЙСТВА АВСТРО-ВЕНГЕРСКОЙ ИМПЕРИИ 1867-1918 ГОДОВ}

А. В. Парфенов, П. Е. Соборнов

Нижегородская академия МВД России

Поступила в редакцию 6 сентября 2019 г.

\begin{abstract}
: one of unstudied problems in legal knowledge there is a decision of specific and essence state-legal device of Austro-Hungarian empire, that during many decades was not put in home and foreign historiography. In the article authors come to the conclusion that state - the legal device of this state possessed the unusual lines of confederative device, not characteristic for most states with the monarchist form of rule. Exactly maintenance of such specific and allowed to the dynasty of Habsburgs to manage large territories of Central Europe during almost fifty years.

Key words: Austro-Hungarian empire, dynasty of Habsburgs, confederation, parliament, emperor.
\end{abstract}

\begin{abstract}
Аннотация: одной из слабоизученных проблем правового знания является Австро-Венгерской илперии, которые на протлжении многих десятилетий не ставились в отечественной и зарубежной историографии. Авторы приходят к выводу о тол, что государственно-правовое устройство этого государства обладало необычныли чертали конфбедеративного устройства, не характерныли для большинства государств с монархической фборлой правления. Иленно сохранение такой специфики и позволило династии Габсбургов управлять большили территорияли Центральной Европь на протяжении почти пятидесяти лет.
\end{abstract}

Ключевые слова: Австро-Венгерская илперия, династия Габсбургов, конфбедераиия, рейхсрат, сейл, илператор.

Одним из слабоизученных вопросов современного историко-правового знания является характеристика государственно-правового устройства Австро-Венгерской империи, распавшейся после Первой мировой войны. Несмотря на фракт того, что во многих государствах Европы и США в 2018 г. прошли памятные мероприятия, в России данное событие осталось незамеченным научной общественностью. Проигнорировали эти переломные события и представители теории и истории государства и права. Данный фракт вряд ли можно назвать случайным. Представляется, что в нем прослеживается определенная закономерность, имеющая достаточно глубокие исторические корни.

Следует отметить, что представления об Австро-Венгерской империи в современной России, как и в СССР, продолжают отличаться фррагмен-

(C) Парфенов А. В., Соборнов П. Е., 2021 
тарностью и известной пробельностью. Знания о ней в большинстве случаев сводятся к констатации ряда историко-политических фрактов. Например, Австро-Венгрия, являясь членом Тройственного союза, наряду с Германией и Италией, выступала противником царской России в Первой мировой войне, поводом для которой послужило убийство наследника престола эрцгерцога Фердинанда. Значительно реже Австро-Венгерская империя вспоминается в контексте своего литературного наследия. В связи с этим она, как правило, преподносится в качестве Родины таких выдающихся писателей, как, например, Ярослав Гашек и Карел Чапек.

Различные аспекты наследия Австро-Венгерской империи могут выступать предметом исследования для целого ряда специалистов, представляющих широкий круг современных областей знания. Среди них, на наш взгляд, наиболее любопытным и требующим особого внимания специалистов является вопрос о государственно-правовом устройстве данной страны. Представители теории и истории государства и права не уделяли ему должного внимания. В результате специфические особенности формы правления, государственного устройства Австро-Венгрии не получили в отечественной монографической литературе должного освещения. Отрывочные сведения, почерпнутые из весьма немногочисленных источников, не позволяют, к сожалению, составить достаточного и полного представления об этом во многом уникальном государстве. Невостребованным остается и накопленный им государственно-правовой опыт, содержание которого, например в области регулирования межнациональных отношений, построения сложного государства, продолжает оставаться актуальным в современных условиях.

К числу важнейших задач настоящей статьи следует отнести, во-первых, попытку выяснения ряда особенностей Австро-Венгерского государства; во-вторых, привлечение внимания научной общественности к обозначенной проблеме.

Истоки игнорирования проблемы Австро-Венгерского государства советскими учеными-правоведами, как нам представляется, следует искать во взглядах классиков марксистско-ленинского учения. В них прослеживается последовательное подчеркнуто отрицательное отношение как к самой Австро-Венгерской империи, так и ее населению. Ф. Энгельс, в частности, заявлял, что «варвары всех языков и народностей соединились под скипетром Габсбургского дома» ${ }^{1}$, немцев «под австрийским фрлагом» он называл «ландскнехтами деспотизма»². Идеи такого рода послужили методологической основой для последующих исследований советских ученых-правоведов и историков. Под этим углом зрения Австро-Венгрия стала традиционно рассматриваться в официальной отечественной науке. Здесь она превратилась в «бурлящий котел социальных и национальных столкновений» ${ }^{3}$. Подобного понимания было достаточно

1 Энгельс Ф. Начало конца Австрии // Соч. М., 1955. Т. 4. С. 472.

${ }^{2}$ Там же. С. 477.

${ }^{3}$ Малая советская энциклопедия / под ред. Н. Л. Мещерякова. М., 1932. Т. 1. C. 80 . 


\section{Вестник ВГУ. Серия: Право}

для формулирования многочисленных критических замечаний, и отсутствие серьезных научных исследований по теме не могло остановить их поток.

В советской историографии 1920-1930 гг. одним из важнейших аспектов в изучении Австро-Венгерской империи становилась революция 1848 г., в контексте которой опыт Австро-Венгерской государственности подвергался всевозможным разоблачениям. Сама монархия Габсбургов подвергалась конъюнктурной критике за попытку «поставить радости и невзгоды миллионов людей в зависимость от мудрости и благоусмотрения одного человека». Разоблачению подвергались идеи монархии Габсбургов как «хранительницы мира среди враждебных противоречий и руководительницы, которая объединяет готовые к разрыву элементы, принуждает их к взаимодействию» ${ }^{4}$. Идеализации подвергалась революция в австрийских и венгерских землях, имела место абсолютизация межнациональных и религиозных конфликтов этого государства, которые якобы были подавлены международной контрреволюцией. Именно поэтому излюбленной тематикой научных работ того периода становились исследования в области специфики подавления революции с помощью российской армии. На страницах ведущего архивоведческого журнала «Красный архив» публиковались, безусловно, ценнейшие документы из российских архивов, которые раскрывали реакцию российского двора императора Николая I на революционные события 1848 г. ${ }^{5}$ Выходили научные статьи, посвященные организации российской интервенции 1848 г., направленной на содействие австрийскому двору в подавлении революции. Вскрывалась контрреволюционная сущность Габсбургской монархии как вдохновительницы подавления революционных перемен, направленных на становление и укрепление буржуазного строя и окончательный слом феодально-крепостнических отношений 6 . В результате всестороннего анализа данных источников отечественной историографической мысли возникает вопрос: каким образом данное государство, занимавшее большие территории Центральной Европы, смогло не только справиться с внутренними социальными потрясениями 1848-1849 гг., но и разрешить острейшие социальные, национальные и религиозные конфоликты, просуществовав еще 70 лет - до 1918 г.? Этот вопрос начал волновать представителей отечественной исторической и историко-правовой мысли, которая начинает интересоваться проблемами причинно-след-

${ }^{4}$ Бах M. История австрийской революции 1848 года / под ред. В. Базарова, И. Степанова. М., 1923. С. 57.

${ }^{5}$ Австрийская революция 1848 года и Николай I // Красный архив. 1938. Т. 4/5. C. $155-207$.

${ }^{6}$ См.: Авербух Р. А. Венгерская революция 1848 года и царская интервенция // Борьба классов. 1932. № 2/3. С. 74-78; Его же. Русская интервенция в венгерской революции 1848-1849 годов // Историк-марксист. 1932. № 3 (25). С. 87-117 ; Его же. Царская интервенция в борьбе с венгерской революцией 1848-1849 годов. М., 1935 ; Ландор Б. Л. Венгерская революция 1848-1849 годов и царская интервенция // Исторические записки. 1940. № 9. С. 243-291. 
ственной обусловленности распада габсбургской Австро-Венгерской империи. В 1927 г. в журнале «Историк-марксист» появился критический обзор иностранной литературы, посвященной распаду Австро-Венгерской империи ${ }^{7}$ В данном обзоре были выявлены различные точки зрения на многоаспектный процесс распада Австро-Венгерской империи, заключавшиеся в развитии процесса федерализации в этом полиэтничном государстве и провале рефрорм, направленных на реформирование общества. При этом в обзоре обращала на себя внимание «абсолютная и относительная бедность исторической литературы о самой Австро-Венгрии», а также фракт, что многие документы и научная литература в основном освещают обстоятельства конфликта, вызвавшего Первую мировую войну и вовлеченность в нее Австро-Венгрии.

Принятие же Конституции СССР в 1936 г., закреплявшей в том числе и основы фредеративного устройства нашей страны в тот период, поставило перед отечественной историко-правовой наукой проблему противопоставления советского типа фредеративных отношений старым формам фредеративных отношений, выраженным в фрункционировании Австро-Венгерской империи, состоявшей «из двух самостоятельных государств - Австрии и Венгрии, соединенных под властью одного монарха, носящего титул австрийского императора и венгерского короля» ${ }^{8}$. Профрессор И. Трайнин в 1937 г. опубликовал статью в журнале «Революция и национальности», которая была посвящена провалу опыта существования многонационального Австро-Венгерского государства. Автор писал о том, что «все попытки редормирования внутреннего устройства Австро-Венгрии наталкивались на непримиримые национальные и религиозные конфоликты, порождая вражду, а сама идея становления фредеративных отношений понималась различными национальностями империи в качестве основы борьбы за независимость» ${ }^{9}$. Распад Австро-Венгерской империи объяснялся субъективными фракторами - развитием социал-демократического движения в период Первой мировой войны, поражением на ее фрронтах, революционными потрясениями в соседней России, влияние которых в процессе распада империи, на наш взгляд, достаточно сильно идеализировалось, а также ростом и обострением национальных противоречий, препятствующих достижению бесконфликтности общества $^{10}$. При этом сущностной чертой в изучении Австро-Венгерской государственности в отечественной историографии к концу 1930 - началу 1940-х гг. стала постановка проблем причинности распада империи, а проблемы типологии и развития государственного строя, эволюции в развитии законодательства дуалистической монархии, проблемы функ-

${ }^{7}$ См.: Тордай A. Распад Австрии. Критический обзор иностранной литературы // Историк-марксист. 1927. № 6. С. 254-259.

${ }^{8}$ Пименова Э. Борьба за свободу Австрии и Венгрии (1848 г.). СПб., 1920. С. 3.

9 Трайнин И. О провале опыта многонационального государства старой Австро-Венгрии // Революция и национальности. 1937. № 2 (84). С. 55-64.

10 См.: Рубинштейн E. Распад Габсбургской монархии 1918 года // Историк-марксист. 1940. № 7. С. 14-34. 


\section{Вестник ВГУ. Серия: Право}

ционирования государственных учреждений этого государства остаются практически неизученными и во второй половине XX - начале XXI в., в связи с постановкой проблем формирования Чехословацкого, Польского, Югославского государств, возникших после распада Австро-Венгерской империи.

Между тем практический опыт функционирования государственных, финансовых и правовых институтов Австро-Венгерской монархии не раз вызывал интерес на разных этапах развития отечественной государственности. В условиях проведения денежной реформы в Советской России в первой половине 1920-х гг. - деятельность Австро-Венгерского государственного банка второй половины XIX - начала XX в. Особое значение для отечественных финнансистов имела «австро-венгерская практика по охране устойчивости национальной валюты, его знаменитая девизная политика... идея о так называемой “валюте с золотым ядром"»11. Система перехода к золотому монометаллизму произошла в 1892 г. в Австро-Венгрии как в одном из первых государств мира. Именно этот опыт и был воплощен в Советском государстве 1920-х гг. Ранее же, в дореволюционный период, по мнению отечественных правоведов, австрийское государственное законодательство не раз подвергалось рецепции (восприятию) отечественной правовой системой, как, например, в случае с практически полностью заимствованным отечественной правовой системой в Австро-Венгерской империи законодательством о престолонаследии во второй половине XIX в.

Российские правоведы конца XIX в. неоднократно обращали внимание на схожесть отдельных элементов абсолютистского государственного устройства Австро-Венгерской и Российской империй ${ }^{12}$. Н. М. Коркунов, в частности, изучал проблемы правового регулирования престолонаследия - замещения высшей монархической власти. Разбирая российское законодательство о престолонаследии, выраженное в «Учреждении об императорской фрамилии» от 5 апреля 1797 г., ученый пришел к выводу о схожести принципов наследования престола с Австрийской империей, изложенных Прагматической санкцией 1713 г., выдвинув само понятие «русско-австрийская система престолонаследия» ${ }^{13}$. Данная система, с точки зрения Н. М. Коркунова, допускала к престолонаследию женщин, в том случае «когда мужское поколение царствующего дома пресечется во всех линиях» ${ }^{14}$.

В чем же состояла специфика Австро-Венгерской империи? Ее сложная структура и многонациональный состав были обусловлены целым рядом событий, имевших место в истории Центральной Европы. Одним

${ }^{11}$ Силин Н. Д. Кредитная политика эмиссионного банка и устойчивая валюта (Австро-Венгерский банк). М., 1928. С. 3.

${ }^{12}$ См.: Градовский А. Д. Собр. соч. : в 9 т. // Государственное право важнейших европейских государств. СПб., 1902. Т. 5. С. 188-189 ; Ивановский В. В. Русское государственное право. Казань, 1896. Ч. 1. С. 74.

${ }^{13}$ Коркунов Н. М. Австрийское наследие : сб. статей. СПб., 1898. С. 303.

${ }^{14}$ Там же. 
из наиболее значимых среди них стало появление «турецкой угрозы». Отпечаток на характер Австро-Венгерского государства наложила борьба с наступлением турок. Во второй половине XV в. они стали представлять реальную угрозу. Как отмечается в Советской исторической энциклопедии, «в борьбе народов Центральной и Юго-Восточной Европы с «турецкой опасностью» австрийские земли Габсбургов... заняли руководящее положение, оказавшись в этот период в политическом отношении сильнее, чем другие страны дунайского бассейна» ${ }^{15}$. Австрия стала центром сопротивления, к которому «притягивались» новые земли и народы. Владения Габсбургов постепенно расширялись. Они, в частности, были дополнены территориями Западной Венгрии и Чехии. Процесс разрастания государства поставил перед властью ряд новых вопросов. Прежде всего, требовалось обеспечить полное подчинение присоединенных территорий, создать эффрективный механизм управления ими. Решение подобных вопросов в конечном итоге и привело к появлению достаточно оригинальной модели Австро-Венгерского государства. Оно прошло длинный путь развития и во второй половине XIX в. стало рассматриваться в качестве империи.

Привычное название данного государства «Австро-Венгерская империя» возникло далеко не сразу. Момент его появления по-разному преподносится в доступной научной литературе. Так, В. В. Битнер утверждал, что название страны: «Австро-Венгерская монархия» («Австро-Венгерская империя») было установлено в 1804 г. $^{16}$ Представляется, что подобное заявление не в полной мере корректно, речь в данном случае идет скорее об Австрийском государстве. Название «Австро-Венгерская империя» появилось позднее и отражало существенные изменения, произошедшие внутри государства. В связи с этим мы, в большей степени, солидарны с авторами Большой советской энциклопедии, полагающими, что в 1867 г. «абсолютистская Австрия была преобразована в конституционно-бюрократическое двуединое государство, получившее название Австро-Венгрии» ${ }^{17}$. В основе данной новеллы лежало соглашение (так называемый австро-венгерский компромисс, или «аусгляйх») с венгерской элитой, устанавливающее господство классов двух наций - австрийцев и венгров. Интересы же остальных, в основном славянских, народов, населявших государство, часто не учитывались. Подобной точки зрения придерживаются и составители советской исторической энциклопедии. По их мнению, «Австро-Венгрия - двуединая (дуалистическая) монархия, созданная в 1867 г. в результате преобразования Австрийской империи

${ }^{15}$ Советская историческая энциклопедия / под ред. Е. М. Жукова. М., 1961. T. 1. C. 106.

${ }^{16}$ См.: Словарь исторический и социально-политический / под ред. В. В. Битнера. СПб., 1906. С. 11.

${ }^{17}$ Большая советская энциклопедия / под ред. С. И. Вавилова. М., 1949. Т. 1. C. 177 . 


\section{Вестник ВГУ. Серия: Право}

на основе соглашения между господствующими классами Австрии и Венгрии» ${ }^{18}$.

Вопрос о территории Австро-Венгерской империи достаточно интересен. $\mathrm{K}$ ее составным частям, как правило, относят Австрийскую империю и Королевство Венгрия. Констатируется, что «монархия Габсбургов была разделена по линии реки Лейта на две части: Австрию (Цислейтания) и Королевство Венгрия (Транслейтания)» ${ }^{19}$. Важно отметить, что позднее к ним присоединились, как отмечают некоторые авторы, оккупированные, согласно Берлинскому трактату 1878 г., провинции Босния и Герцеговина (номинально числящиеся во владении Турции) ${ }^{20}$.

Специфика Австро-Венгерской империи как оригинального самостоятельного государства требует внимания со стороны ученых-правоведов. Для ее осмысления необходимо провести тщательное изучение формы данного государства. Считаем необходимым подчеркнуть, что данная проблема нуждается в отдельном специальном исследовании. В рамках статьи имеем возможность обратить внимание читателя лишь на ряд достаточно любопытных нюансов.

По форме правления Австро-Венгерская империя относилась к ограниченным монархиям. Ее главой являлся монарх, имевший титул «Император Австрийский и Король Венгерский». 21 декабря 1867 г. Франц Иосифр I санкционировал конституцию Австрии. Она наряду с рейхсраmол в Австрии и сейлол в Венгрии была призвана ограничить власть монарха. Тем не менее император Австрийский и король Венгерский продолжал оставаться достаточно сильной фигурой и обладал широким кругом властных полномочий. $K$ их числу, в частности, можно отнести решение вопроса о войне и мире, верховное командование армией и фрлотом, право помилования.

В модели Австро-Венгерской империи монарх делил власть с законодательным органом. В связи с этим данное государство традиционно относят к дуалистическим монархиям. Вместе с тем есть основания говорить о том, что на практике значение органов законодательной власти оказывалось не столь велико, как принято считать. При желании монарх имел возможность влиять на их состав, деятельность и, в целом, не был ими «связан». Рассмотрим данный вопрос подробнее. Для его решения, в первую очередь, следует выяснить, что же представляла собой законодательная власть в данном государстве?

Одна из существенных особенностей Австро-Венгерской империи состояла в том, что в ней не существовало постоянно действующего парламента. На территории Австрии фонкционировал рейхсрат, в Венгрии -

18 Советская историческая энциклопедия / под ред. Е. М. Жукова. М., 1961. T. 1. C. 139.

${ }^{19}$ Большая советская энциклопедия / под ред. С. И. Вавилова. Т. 1. С. 177.

${ }^{20}$ См.: Брокгауз Ф. А., Ефброн И. А. Энциклопедический словарь. Дополнительный том 1. СПб., 1905. С. 31 ; Павленков Ф. Энциклопедический словарь. 4-е изд. СПб., 1910. С. 22. 
сейл. Каждый из них решал отнесенные к его компетенции вопросы местного значения и обладал специфической структурой. Например, рейхсрат состоял из двух палат - палаты господ с назначаемым правительством членами (пожизненными и наследственными) и палаты депутатов, члены которой в количестве 343 человека избирались населением от разных земель ${ }^{21}$.

Законодательная власть по общим делам осуществлялась парламентами Австрии и Венгрии при посредстве делегаций, которые выступали в роли Австро-Венгерского парламента. Они ежегодно выбирались заново и созывались императором поочередно в Вене и Будапеште. Каждая половина монархии направляла в делегацию по 60 человек: 20 - из палаты господ и 40 - из палаты депутатов. Делегации Австрии и Венгрии заседали раздельно. Коммуникация между ними осуществлялась в письменной форме. При возникновении разногласий они собирались в одно заседание и голосовали без каких-либо прений ${ }^{22}$.

Формально делегации самостоятельно осуществляли законодательную власть. Однако действовавшее право предусматривало ряд «лазеек», которыми в случае необходимости мог воспользоваться император. Как отмечалось выше, он созывал делегации и соответственно имел возможность в своих интересах устанавливать время их сбора. Кроме того, при необходимости он мог корректировать состав рейхсрата, дополнительно назначая в него «пожизненных членов» ${ }^{23}$.

Любопытно, что по действовавшей конституции круг властных полномочий императора был настолько широк, что при желании он мог придать своей воле форму закона без какого-либо участия со стороны законодательных органов. Так, ст. 14 гласила: «Если в то время, когда рейхсрат не созван, является крайняя необходимость в мероприятиях, для которых по конституции необходимо согласие рейхсрата, то таковые под общею ответственностью всего министерства могут приниматься посредством императорских декретов... Такие декреты имеют временно силу закона, если они подписаны всеми министрами. Они теряют силу закона, если правительство не представит их ближайшему рейхсрату или если они не получат одобрения от рейхсрата» ${ }^{24}$.

Реализация положений ст. 14 дает монарху возможность принимать решения по важнейшим вопросам государственно-правовой жизни без учета мнения представителей законодательной власти. Непопулярные в их глазах акты можно «провести» в так называемый межсессионный период. При возникновении потребности принятия заведомо «непроход-

${ }^{21}$ См.: Словарь исторический и социально-политический / под ред. В. В. Битнера. СПб., 1906. С. 14.

${ }^{22}$ См.: Энциклопедический словарь / под ред. В. Я. Железнова [и др.]. 8-е стер. изд. М., 1900. Т. 1. С. 259.

${ }^{23}$ См.: Большая советская энциклопедия / под ред. С. И. Вавилова. Т. 1. C. $180-181$.

${ }^{24}$ Цит. по: Брокгауз Ф. А., Ефрон И. А. Энциклопедический словарь. Дополнительный том 1. С. 26. 


\section{Вестник ВГУ. Серия: Право}

ного» в органе законодательной власти решения он может быть распущен.

Наличие декретов императора, имевших силу закона, наряду с другими выделенными нами нюансами, свидетельствует о том, что роль законодательной власти в Австро-Венгерской империи была не столь велика, как в классических дуалистических монархиях. Указанные факты позволяют несколько усомниться в реальности власти рейхсрата, сейма и делегаций. Есть основания выдвинуть предположение, что данные субъекты в ряде случаев обеспечивали лишь формальное утверждение решений императора.

Традиционно считается, что империя обладает сильной исполнительной властью, представленной, прежде всего, правительством, имеющим сложную структуру и общую компетенцию. В случае с Австро-Венгрией можно наблюдать некоторый отход от устоявшегося шаблона. В ней было сорормировано всего 3 общих министерства: а) иностранных дел; б) военное и морское; в) фринансов. Такое количество считалось вполне достаточным, ибо основные направления деятельности названных министерств в полной мере охватывали так называемые «общие дела» империи.

Отмеченная особенность была тесно связана с фрормой государственного устройства Австро-Венгрии, которая, как и фрорма его правления, имеет ряд нюансов. Рассматриваемое государство может быть отнесено к числу сложных. Австро-Венгрия состояла из двух формально независимых государств - Австрии и Венгрии. Каждое из них имело собственную конституцию, органы законодательной (рейхсрат в Австрии и сейм в Венгрии) и исполнительной власти (так, помимо «общих» министерств, на территории каждой части империи фрункционировали свои министерства).

После реформ 1867 г. между Австрией и Венгрией была установлена двоякого рода связь: политическая и фринансовая. Первая, имевшая постоянный характер, проявлялась в наличии общего главы государства, общих министерств и делегаций. Вторая - обладала временным характером и должна была возобновляться каждые 10 лет посредством «законов о соглашении» (Ausgleichgesetze). С их помощью устанавливались: доля участия каждой части империи в общих расходах (например, в 1867 г. доля общих расходов для Австрии составляла 70 \%; для Венгрии - 30 \%); доля участия в расходах по общему государственному долгу; таможенный и торговый союз. Начиная с 1867 г. «законы о соглашении» возобновлялись в 1878, 1887 и в 1907 гг. ${ }^{25}$

Как справедливо отмечал Ф. Павленков, во всех отношениях, за исключением области внешних дел, армии и фринансов, Австрия и Венгрия были совершенно независимы ${ }^{26}$. После ознакомления с вышеизложенным материалом подобный вывод представляется вполне оправданным.

${ }^{25}$ См.: Энциклопедический словарь / под ред. В. Я. Железнова [и др.]. Т. 1. C. 257-258.

${ }^{26}$ См.: Павленков Ф. Энциклопедический словарь. 4-е изд. СПб., 1910. С. 22. 
Однако современный ученый-правовед может с легкостью заметить, что некоторые принципы построения Австро-Венгерской империи во многом «перекликаются» с идеями, положенными в основу такой формы государственного устройства, как конфедерация. Действительно, сохранение самостоятельности Австрией и Венгрией, наличие общих органов управления в лице трех министерств позволяют нам сегодня проводить некоторые параллели. Вместе с тем нужно понимать, что декларируемые самостоятельность и независимость частей империи на деле служили фрасадом, за которым были спрятаны истинные интересы правящей Габсбургской династии. Им удалось сформировать внешне притягательную модель государства, которая позволила ликвидировать опасность полного отделения Венгрии, найти компромисс с австрийской буржуазией посредством предоставления ей конституционных прав, договориться с крупными венгерскими землевладельцами, понизить уровень активности сепаратистских и революционных движений. Ряд созданных на основе демократических начал государственно-правовых институтов не смог стать помехой для принятия императором непопулярных, порой вредных для общества, решений. Вместе с тем сложившаяся модель Австро-Венгерской империи интересна ученому-правоведу уже тем, что она не вписывается в привычную схему монархий. Представляется, что есть все основания отнести ее к числу нетипичных.

Настоящая статья может расцениваться в качестве первого шага, связанного с изучением особенностей неоправданно забытой, игнорируемой большинством исследователей Австро-Венгерской империи. Ее наиболее важные и любопытные для специалистов черты должны стать объектом будущих специальных исследований.

\section{Библиографический список}

Авербух Р. А. Венгерская революция 1848 года и царская интервенция // Борьба классов. 1932. № 2/3. С. 74-78.

Авербух Р. А. Русская интервенция в венгерской революции 1848-1849 годов // Историк-марксист. 1932. № 3 (25). С. 87-117.

Авербух $P$. А. Царская интервенция в борьбе с венгерской революцией 1848-1849 годов. М. : Соцэкгиз, 1935. 332 с.

Австрийская революция 1848 года и Николай I // Красный архив. 1938. T. 4/5 (89/90). С. 155-207.

Бах М. История австрийской революции 1848 года / под ред. В. Базарова, И. Степанова. М. : Госиздат, 1923. 576 с.

Большая советская энциклопедия / под ред. С. И. Вавилова. М. : Большая советская энциклопедия, 1949. Т. 1.718 с.

Брокгауз Ф. А., Ефрон И. А. Энциклопедический словарь. Дополнительный том 1. СПб. : Типография акционерного общества «Брокгауз - Ефрон», 1905. $488 \mathrm{c}$.

Градовский А. Д. Собр. соч. : в 9 т. // Государственное право важнейших европейских государств. СПб., 1902. Т. 5. 561 с.

Ивановский В. В. Русское государственное право. Казань, 1896. Ч. 1. $276 \mathrm{c}$. 
Коркунов Н. М. Австрийское наследие : сб. статей. СПб., 1898. С. 302-303.

Ландор Б. Л. Венгерская революция 1848-1849 годов и царская интервенция // Исторические записки. 1940. № 9. С. 243-291;

Малая советская әнциклопедия / под ред. Н. Л. Мещерякова. М., 1932. T. $1.376 \mathrm{c}$.

Павленков Ф. Энциклопедический словарь. 4-е изд. СПб. : Тип. Ю. Н. Эрлих, 1910. 1559 с.

Пименова Э. Борьба за свободу Австрии и Венгрии (1848 г.). СПб., 1920. $64 \mathrm{c}$.

Рубинштейн E. Распад Габсбургской монархии 1918 года // Историк-марксист. 1940. № 7. С. 14-34.

Силин Н. Д. Кредитная политика эмиссионного банка и устойчивая валюта (Австро-Венгерский банк). М., 1928. 289 с.

Словарь исторический и социально-политический / под ред. В. В. Битнера. СПб. : Вестник знания, 1906. 625 с.

Советская историческая энциклопедия / под ред. Е. М. Жукова. М. : Советская энциклопедия, 1961. Т. 1. 530 с.

Тордай А. Распад Австрии. Критический обзор иностранной литературы // Историк-марксист. 1927. № 6. С. 254-259.

Трайнин И. О провале опыта многонационального государства старой Австро-Венгрии // Революция и национальности. 1937. № 2 (84). С. 55-64.

Энгельс Ф. Начало конца Австрии // Соч. М., 1955. Т. 4. С. 471-478.

Энциклопедический словарь / под ред. В. Я. Железнова [и др.]. 8-е стер. изд. М., 1900. Т. 1. 414 с.

\section{References}

Averbukh R.A. Hungarian Revolution of 1848 and tsarist intervention // Class struggle. 1932. № 2/3. P. 74-78.

Averbukh R. A. Russian intervention in the Hungarian revolution of 18481849 // Marxist historian. 1932. № 3 (25). P. 87-117.

Z Averbukh R. A. Tsarist intervention in the fight

The Austrian Revolution of 1848 and Nicholas I // Red Archive. 1938. T. 4/5 (89/90). P. 155-207.

Bach M. History of the Austrian Revolution of 1848/Edited by V. Bazarov,

70 I. Stepanov. M. : Gosizdat, 1923. 576 p.

Big Soviet Encyclopedia/Ed. S.I. Vavilova. T. I. M. : Great Soviet Encyclopedia, 1949. $718 \mathrm{p}$.

Brockhaus F. A., Efron I. A. Encyclopedic Dictionary. Additional volume I. St. Petersburg: Printing house of the Brockhaus-Efron Joint-Stock Company, 1905. $488 \mathrm{p}$.

Gradousky A. D. Collected works in nine volumes // State law of the most important European states. St. Petersburg, 1902. T. 5. 561 p.

Ivanovsky V. V. Russian state law. Ch.1. Kazan, 1896. 276 p.

Korkunov N. M. Austrian heritage. Collection of articles by N. M. Korkunov. St. Petersburg, 1898. P. 302-303.

Landor B. L. Hungarian revolution of 1848-1849 and tsarist intervention // Historical notes. 1940. № 9. P. 243-291. 


\section{Теория и история государства и права}

Small Soviet Encyclopedia/Ed. N.L. Meshcheryakova. M., 1932. T. 1. 376 p.

Pavlenkov F. Encyclopedic dictionary. 4th ed. St. Petersburg: Type. Yu.N. Ehrlich, 1910. 1559 p.

Pimenova E. The struggle for the freedom of Austria and Hungary (1848). Petersburg, 1920. 64 p.

Rubinstein E. The collapse of the Habsburg monarchy of 1918 // Marxist historian. 1940. № 7. P. 14-34.

Silin N. D. Credit policy of the issuing bank and stable currency (AustroHungarian Bank). M., 1928. 289 p.

Dictionary of historical and socio-political/Ed. V.V. Bitner. St. Petersburg: Bulletin of Knowledge, 1906. 625 p.

Soviet Historical Encyclopedia/Ed. E.M.Zhukov. T. 1. M. : Soviet Encyclopedia, 1961. 530 p.

Tordai A. Disintegration of Austria/Critical review of foreign literature // Marxist historian. 1927. № 6. P. 254-259.

Trainin $I$. On the failure of the experience of the multinational state of old Austria-Hungary // Revolution and nationality. 1937. № 2 (84). P. 55-64.

Engels F. Beginning of the end of Austria // Works. M., 1955. T. 4. P. 471-478.

Encyclopedic Dictionary / Ed. V.Ya. Zheleznova [et al.]. 8th stereotype. ed. M., 1900. T. 1.414 p.

\section{Для иитирования:}

Парфбенов А. В., Соборнов П. Е. О нетипичных формах правления : специфрика и сущность государственно-правового устройства Австро-Венгерской империи 1867-1918 годов // Вестник Воронежского государственного университета. Серия: Право. 2021. № 3 (46). C. 60-71. DOI: https://doi.org/10.17308/ vsu.proc.law.2021.3/3540

\section{Recommended citation:}

Parfenov A. V., Sobornov P. E. To question about offtype forms of rule : specific and essence state-legal device of Austro-Hungarian empire is 1867-1918 years // Proceedings of Voronezh State University. Series: Law. 2021. № 3 (46). P. 60-71. DOI: https://doi.org/10.17308/vsu.proc.law.2021.3/3540

Нижегородская академия МВД Россиu

Парфбенов А. В., кандидат юридических наук, профбессор кафеедры теории и истории государства и права, доцент, полковник полиции

E-mail:Parfen-AV@mail.ru

Соборнов П. Е., кандидат исторических наук, доцент каббедры теории и истории государства и права, старший лейтенант полиции

E-mail: sobornovpavel@inbox.ru
Nizhny Novgorod Russian Interior Ministry Academy

Parfenov A. V., Candidate of Legal Sciences, Professor of the Theory and History of State and Law Department, Associate Professor, Colonel of Police

E-mail: Parfen-AV@mail.ru

Sobornov P. E., Candidate of Historical Sciences, Associate Professor of the Theory and History of State and Law Department, Senior Police Lieutenant

E-mail: sobornovpavel@inbox.ru 